\title{
CYP3A4*18 Allele
}

National Cancer Institute

\section{Source}

National Cancer Institute. CYP3A4*18 Allele. NCI Thesaurus. Code C46027.

Human CYP3A4*18 allele is located in the vicinity of 7q21.1 and is approximately $27 \mathrm{~kb}$ in length. This allele, a variant form of the CYP3A4 wild-type allele, encodes cytochrome P450 3A4*18 protein. The CYP3A4*18 allele exhibits a clinically-relevant SNP (g.20070T >C) in exon 10 that results in a L293P coding change. This alteration in protein sequence dramatically increases the enzymatic activity of the cytochrome P450 3A4*18 protein. 